ORIGINAL ARTICLE

\title{
Blood film examination for vacuolated lymphocytes in the diagnosis of metabolic disorders; retrospective experience of more than 2500 cases from a single centre
}

\author{
G Anderson, V V Smith, M Malone, N J Sebire
}

J Clin Pathol 2005;58:1305-1310. doi: 10.1136/icp.2005.027045

See end of article for authors' affiliations

Correspondence to:

Dr N J Sebire, Department of Histopathology,

Camelia Botnar

Laboratories, Great

Ormond Street Hospital,

Great Ormond Street,

London WCIN 3JH, UK;

SebirN@gosh.nhs.uk

Accepted for publication 6 April 2005
Background: A range of metabolic diseases can result in abnormal accumulation of metabolic byproducts, resulting in abnormal lymphocyte cytoplasmic vacuolation, identifiable on routine blood film examination. Aims: This study retrospectively examines the usefulness of blood film examination for vacuolated lymphocytes in a specialist paediatric pathology department in relation to patient's age and presentation. It also describes specific diagnostic features in relation to specific classes of metabolic disease.

Methods: Retrospective review of a histopathology database to identify all blood films examined for the detection of vacuolated lymphocytes during a 15 year period (1989-2004).

Results: In total, 2550 blood films were investigated. The median age at submission was 2 years (range, birth to 88 ), and $>90 \%$ of samples were from children $<18$ years. The most common indications were developmental delay/regression, ataxia, seizures, and cardiomyopathy. Vacuolated lymphocytes were identified in 156 films (6.1\%). The frequency of vacuolated lymphocytes varied with clinical presentation, with ophthalmic indications having the highest positive rate (40\%). In cases with vacuolated lymphocytes, a wide range of underlying metabolic diagnoses was apparent, the most common being juvenile neuronal ceroid lipofuscinosis and acid maltase deficiency, which accounted for more than half of the diagnoses. Conclusions: The examination of blood films for lymphocyte vacuolation is clinically useful in patients with a history suggestive of metabolic disease. The test is cheap, rapid, minimally invasive, and provides first line screening, with some findings indicating clues to a specific underlying diagnosis.
$\mathrm{F}$ or many years it has been recognised that a range of metabolic diseases resulting in abnormal accumulation of metabolic byproducts may exhibit abnormal cytoplasmic vacuolation of lymphocytes, ${ }^{1}$ identifiable on routine blood film examination. These diseases include Batten's disease (neuronal ceroid lipofuscinosis), ${ }^{2-4}$ Salla disease, ${ }^{5}$ I cell disease, ${ }^{67} \beta$ galactosidase deficiency (GMl gangliosidosis), ${ }^{8}{ }^{9}$ mucopolysaccharidoses, ${ }^{10}$ Niemann-Pick disease, ${ }^{11}$ fucosidosis, ${ }^{12}$ mannosidosis, ${ }^{13}$ Wolman's disease,${ }^{14}$ and glycogenoses. ${ }^{15}$ Because peripheral blood sampling is performed for a variety of investigations in children with a history suggestive of or consistent with metabolic disease, and because the volume of blood required for such testing is small, screening of blood films for the presence of vacuolated lymphocytes should be considered as a first line investigation in such cases, especially in childhood. There are case reports and small series reporting the variety of specific metabolic diseases that may be associated with vacuolated lymphocytes in peripheral blood films, ${ }^{2-15}$ but routine use of this test is not widespread, and no large scale published screening studies are available.

\begin{abstract}
"A range of metabolic diseases resulting in abnormal accumulation of metabolic byproducts may exhibit abnormal cytoplasmic vacuolation of lymphocytes, identifiable on routine blood film examination"
\end{abstract}

The aim of our study was to examine retrospectively the usefulness of blood film examination for vacuolated lymphocytes in a specialist paediatric pathology department during a 15 year period in relation to patient's age and presentation, and to describe the specific diagnostic features of such abnormal vacuolation in relation to specific classes of metabolic disease.

\section{METHODS}

The department of paediatric pathology, Great Ormond Street Hospital, London, UK is a tertiary referral centre for paediatric pathological specimens and, in conjunction with the Institute of Child Health, has special expertise in the diagnosis of childhood metabolic diseases. Blood films for a wide range of indications pertaining to metabolic disease are routinely examined. A search of the histopathology database was carried out to identify all cases of blood film examination for the detection of vacuolated lymphocytes carried out during a 15 year period (1989-2003 inclusive). All results were anonymised and the clinical history provided at the time of examination and results of blood film examination reviewed. Indication groups were categorised according to the major recognised clusters of clinical features for which a metabolic storage disease associated with vacuolated lymphocytes may be suspected.

Therefore, many patients may have had more than one such feature, but in those with multiple symptoms or signs listed on the request form, the primary presentation was used for classification purposes. The prevalence of vacuolated lymphocytes in each presentation group was calculated and the significance of any differences in proportions between groups determined using comparison of proportions test. ${ }^{16}$ Details of cases in which vacuolated lymphocytes were present were grouped according to diagnosis. Our study was approved by the hospital ethics committee.

\section{RESULTS}

During the study period (1989-2003 inclusive), 2550 blood film specimens were submitted to be examined for the presence of vacuolated lymphocytes. The median age at submission was 2 years (range, birth to 88 years), with more than $90 \%$ of cases being children $<18$ years of age (fig 1 ). 

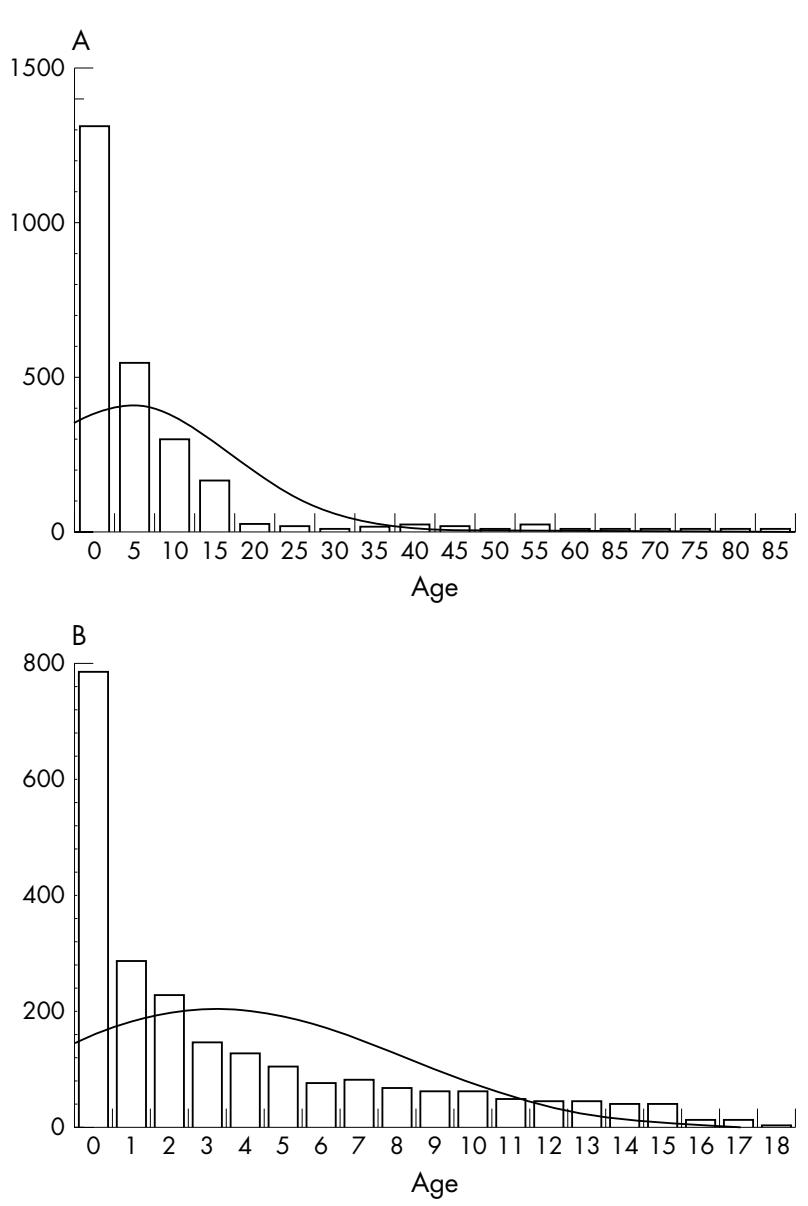

Figure 1 Histograms showing the age distributions at the time of submission of blood film examination in (A) all 2550 cases and (B) those aged 18 or less (2318 patients; $91 \%$ ).

Table 1 shows the main clinical indications for blood film examination. Unfortunately, many specimens (around 30\%) were submitted with either no clinical history provided at all, the request form simply stating "blood for vacuolated lymphocytes", or an inadequate history provided, such as "?metabolic disorder". Because samples are received from a large number of hospitals it was not practical to contact the requesting clinician for each case. However, in cases where vacuolated lymphocytes were detected, further investigation was dictated by more detailed clinical history provision after the initial screen. The most common indications where history was provided were developmental delay/regression, ataxia, seizures, and cardiomyopathy. More recently, in addition to the major neurological and developmental indications, blood film examination has become an integral part of the examination of patients presenting with clinical cardiomyopathy; this accounted for 224 (9\%) cases, with 148 $(66 \%)$ of these submitted in the past five years.

Because blood film examination is essentially a screening test, it would be expected that most cases would be negative for the presence of vacuolated lymphocytes. This is borne out by the finding that vacuolated lymphocytes were identified in 156 of the overall group of 2550 blood films (6.1\%). Table 1 shows the frequency of identification of vacuolated lymphocytes according to the clinical presentation group. In those cases in which vacuolated lymphocytes were present, a wide range of underlying diagnoses were apparent (table 2). In most of the cases, confirmation of the diagnosis was carried out by enzyme analysis, where this was available, or electron microscopic examination of a buffy coat blood sample. In addition to the presence or absence of vacuolated lymphocytes, the characteristics of the vacuolation may provide further indications as to the specific underlying diagnosis (table 3; fig 2). The prevalence of samples positive for vacuolated lymphocytes varied with the clinical indication group (table 1). The single most predictive indication of a positive test result was in association with ophthalmic features, such as progressive blindness and/or fundoscopic abnormalities, in which almost $40 \%$ of the cases had vacuolated lymphocytes. The most common indicationsnon-specific developmental delay and seizures-were associated with significantly lower frequencies of identification of vacuolated lymphocytes compared with the overall population. The group of miscellaneous indications included cases in which some clinical history was provided, but which could not be classified into another distinct category; in this group the prevalence of the detection of vacuolated lymphocytes was not significantly different from the overall group.

\section{DISCUSSION}

Our findings have shown that the pathological examination of blood films for the presence of vacuolated lymphocytes can provide clinically useful diagnostic information in patients with a wide range of complex clinical presentations. This is a cheap, easily performed, and rapid test that can be carried out as part of the screening process in all cases with suspected metabolic disease. In our series, vacuolated lymphocytes were present in around $6 \%$ of cases, indicating a diagnosis of metabolic storage disease. The range of possible associated metabolic abnormalities is wide (table 2), so that further

Table 1 Categorisation of 2550 blood film samples submitted to a single unit for examination of blood films for presence of vacuolated lymphocytes

\begin{tabular}{lllll}
\hline Indication group & $\mathrm{N}(\%$ of total) & Median age (range) & $\begin{array}{l}\text { Frequency vacuolated } \\
\text { lymphocytes (\%) }\end{array}$ & Frequency compared with overall \\
\hline $\begin{array}{llll}\text { No clinical details } \\
\text { Developmental regression/ }\end{array}$ & $729(28.6)$ & $3(0-86)$ & $66 / 729(9.1 \%)^{*}$ & $Z=-2.78, p<0.01$ \\
delay & $559(21.9)$ & $2(0-59)$ & $17 / 559(3.0 \%)^{*}$ & $Z=2.87, p<0.01$ \\
Seizures & $305(12.0)$ & $3(0-81)$ & $6 / 305(2.0 \%)^{*}$ & $Z=2.96, p<0.01$ \\
Ataxia/dystonia & $283(11.1)$ & $6(0-88)$ & $11 / 283(3.9 \%)$ & $Z=1.51, p=0.11$ \\
Cardiomyopathy & $224(8.8)$ & $0(0-57)$ & $11 / 224(4.9 \%)$ & $Z=0.73, p=0.47$ \\
Miscellaneous & $197(7.7)$ & $0(0-79)$ & $9 / 197(4.6 \%)$ & $Z=0.88, p=0.36$ \\
Hepatosplenomegaly & $109(4.3)$ & $0(0-36)$ & $10 / 109(9.2 \%)$ & $Z=-1.29, p=0.16$ \\
Ophthalmic & $64(2.5)$ & $7(0-29)$ & $19 / 64(39.7 \%)^{*}$ & $Z=-7.45, p<0.0001$ \\
Family history & $45(1.8)$ & $5(0-25)$ & $6 / 45(13.3 \%)^{*}$ & $Z=-1.98, p=0.04$ \\
Failure to thrive & $28(1.0)$ & $0(0-8)$ & $0 / 28(0 \%)$ & $Z=1.40, p=0.14$ \\
Respiratory failure & $7(0.3)$ & $39(0-78)$ & $1 / 7(14.2 \%)$ & $156 / 2550(6.5 \%)$ \\
Overall & $2550(100)$ & $2(0-88)$ & & $Z .90, p=0.21$ \\
\hline * $<0.05$. & & &
\end{tabular}



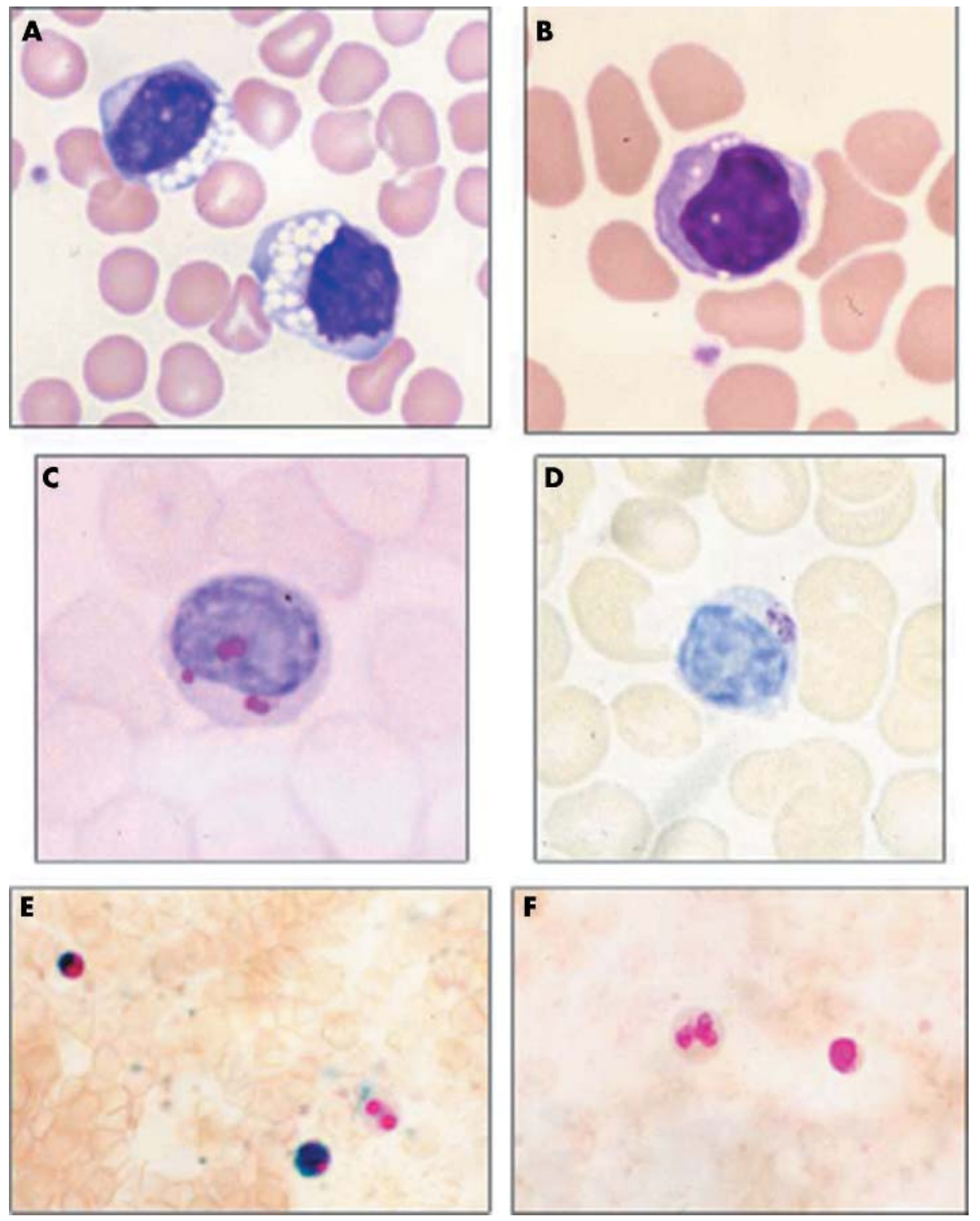

Figure 2 Photomicrographs of blood films submitted for examination for the presence of vacuolated lymphocytes.

(A) Routine May-Grunwald-Giemsa stained blood film showing two lymphocytes with many large bold vacuoles, such as are seen in GMI gangliosidosis, and juvenile Batten's disease. (B) Routine May-GrunwaldGiemsa stained blood film showing a lymphocyte with discrete small vacuoles seen in Pompe's disease and adult acid maltase deficiency. (C) Periodic acid Schiff (PAS) stained blood film showing a lymphocyte with PAS positive inclusions in Pompe's disease and adult acid maltase deficiency. (D) Tolvidine blue stained blood film showing metachromatic cytoplasmic inclusions in a lymphocyte. (E) Enzyme histochemical demonstration of $\beta$ galactosidase in a blood film showing normal enzyme activity in a lymphocyte and eosinophil but negative activity in a neutrophil. (F) Enzyme histochemical demonstration of $\beta$ galactosidase in a blood film showing absent enzyme activity in a lymphocyte and a granulocyte seen in GM1 gangliosidosis and galactosialidosis. investigations may be directed by both the details of the clinical presentation and the characteristics of the lymphocyte vacuolation present (table 3). For example, in the juvenile subtype of Batten's disease (neuronal ceroid

Table 2 Diagnoses in 156 patients in whom vacuolated lymphocytes were detected on peripheral blood film examination

\begin{tabular}{lll}
\hline Diagnosis & N & \% Of total \\
\hline Juvenile Batten's disease (NCL3) & 49 & 31.4 \\
GM1 gangliosidosis & 14 & 9 \\
Galactosialidosis & 7 & 4.5 \\
Salla disease & 2 & 1.3 \\
Neuraminidase deficiency & 2 & 1.3 \\
Pompe's disease/adult acid maltase deficiency & $24 / 12$ & $15.4 / 7.7$ \\
Mannosidosis & 2 & 1.3 \\
Fucosidosis & 3 & 1.9 \\
I cell disease & 6 & 3.8 \\
Niemann-Pick A & 4 & 2.6 \\
Mucopolysaccharidosis & 7 & 4.5 \\
No specific confirmation & 24 & 15.4 \\
\hline
\end{tabular}

lipofuscinosis type 3; NCL3), numerous large distinct cytoplasmic vacuoles are present with no specific tinctorial staining features, whereas acid maltase deficiency (infantile Pompe's disease or adult acid maltase deficiency) is associated with one to six small distinct cytoplasmic vacuoles, which stain strongly with periodic acid Schiff after celloidin protection of the highly soluble form of the stored glycogen. ${ }^{1}$ It should be noted that vacuolated lymphocytes are less frequent in the adult form of the disease than in Pompe's disease (fig 2). We found that the diagnoses were neuronal ceroid lipofuscinosis type 3 and acid maltase deficiency in $31 \%$ and $23 \%$ of blood films with vacuolated lymphocytes, respectively. Because a large number of blood samples were received from external sources in our series, enzymological confirmation was not available in $15 \%$ of cases, the provisional diagnosis being on the basis of the clinical features and lymphocyte vacuolation characteristics.

The technique of blood film examination for the presence of vacuolated lymphocytes requires examination of the thin end of the film near the tail, rather than the thicker region (fig 3). The blood film should be examined in a systematic manner, with particular regard to the detection and morphological characteristics of the lymphocytes. It should 
Table 3 Summary of diagnostic features in selected metabolic diseases in which vacuolated lymphocytes may be identified in peripheral blood films

\begin{tabular}{|c|c|c|c|c|c|}
\hline Disease & OMIM & Enzyme defect & Genetics & Lymphocyte characteristics & Gold standard for diagnosis \\
\hline $\begin{array}{l}\text { Pompe's disease (glycogen } \\
\text { storage disease type 2) } \\
\text { Adult acid maltase } \\
\text { deficiency }\end{array}$ & 232300 & $\begin{array}{l}\text { Acid } \alpha 1,4 \text {-glucosidase (acid } \\
\text { maltase) deficiency }\end{array}$ & $\begin{array}{l}\text { AR; } 17 q 25.2- \\
\text { q25.3; } \\
\text { mutations in the } \\
\text { gene encoding } \\
\text { acid } \\
\alpha \text { glucosidase } \\
\text { (GAA) }\end{array}$ & $\begin{array}{l}1-6 \text { small, discrete, PAS positive } \\
\text { vacuoles }\end{array}$ & Enzyme assay on cultured fibroblasts \\
\hline $\begin{array}{l}\text { Salla disease (sialic acid } \\
\text { storage disease) }\end{array}$ & $\begin{array}{l}269920 \\
604369\end{array}$ & $\begin{array}{l}\text { Sialin (sialic acid transporter } \\
\text { protein) deficiency }\end{array}$ & $\begin{array}{l}\text { AR; } 6 \text { q14-q15; } \\
\text { mutations in } \\
\text { SLC17A5 }\end{array}$ & ;Numerous small vacuoles & $\begin{array}{l}\text { Urine analysis for sialic acid; } \\
\text { vacuolated lymphocytes }\end{array}$ \\
\hline $\begin{array}{l}\text { Sialidosis type } 2 \\
\text { Neuraminidase deficiency } \\
\text { with } \alpha \text { galactosidase } \\
\text { deficiency } \\
\text { (galactosialidosis) }\end{array}$ & $\begin{array}{l}256550 \\
256540\end{array}$ & $\begin{array}{l}\text { Neuraminidase deficiency } \\
\alpha \text { Neuraminidase and } \\
\alpha \text { galactosidase deficiency } \\
\text { secondary to cathepsin A/ } \\
\text { lysosomal protective protein } \\
\text { deficiency }\end{array}$ & $\begin{array}{l}A R ; 6 p 21.3 \\
A R ; 20 q 13.1\end{array}$ & $\begin{array}{l}\text { Numerous large bold vacuoles } \\
\text { Numerous large bold vacuoles }\end{array}$ & $\begin{array}{l}\text { Enzyme assay of cultured fibroblasts } \\
\text { Enzyme assay of cultured fibroblasts; } \\
\text { histochemical } \beta \text { galactosidase } \\
\text { detection on blood films, but } \\
\text { neuraminidase not possible on blood } \\
\text { films }\end{array}$ \\
\hline $\begin{array}{l}\text { I cell disease (muco- } \\
\text { lipidosis II) }\end{array}$ & 252500 & $\begin{array}{l}N \text {-Acetyl glucosaminyl- } \\
\text { phosphotransferase deficiency }\end{array}$ & AR; $4 q 21-23$ & Numerous large bold vacuoles & $\begin{array}{l}\text { Iso-screen of plasma for aryl sulfatase } \\
\text { A; fibroblast culture in which all } \\
\text { lysosomal enzymes are negative }\end{array}$ \\
\hline GM1 ganglosidosis & 230500 & $\beta$ Galactosidase deficiency & $A R ; 3 p 21.33$ & $\begin{array}{l}\text { Numerous large bold vacuoles; } \\
\text { eosinophil granules are large, grey, } \\
\text { and sparse }\end{array}$ & $\begin{array}{l}\text { Enzyme assay of white blood cells } \\
\text { and fibroblasts; histochemical } \beta- \\
\text { galactosidase detection on blood } \\
\text { films, absent in lymphocytes and } \\
\text { neutrophils }\end{array}$ \\
\hline $\begin{array}{l}\text { MPS 1H (Hurler) } \\
\text { MPS is (Scheie) }\end{array}$ & 607014 & $\alpha \mathrm{L}-\mathrm{Id}$ urinidase deficiency & AR; $4 p 16.3$ & $\begin{array}{l}\text { Occasional vacuoles in occasional } \\
\text { lymphocytes, some with basophilic }\end{array}$ & \\
\hline MPS IH/S (Hurler-Scheie) & 607016 & & & $\begin{array}{l}\text { inclusions (Gasser cells); } \\
\text { metachromatic inclusions in }<5 \% \text { of } \\
\text { lymphocytes; vacuoles in } 5-10 \% \text { of } \\
\text { lymphocytes in MPS } 1 \mathrm{H} / \mathrm{S}\end{array}$ & $\begin{array}{l}\text { Enzyme assay on white blood cells; } \\
\text { urinary glycosaminoglycans }\end{array}$ \\
\hline MPS 2 (Hunter) & 309900 & Iduronate sulfatase deficiency & $X$ linked; Xq28 & $\begin{array}{l}\text { Occasional lymphocyte with } \\
\text { occasional vacuoles; metachromatic } \\
\text { inclusions in }<20 \% \text { of lymphocytes }\end{array}$ & $\begin{array}{l}\text { Enzyme assay on white blood cells; } \\
\text { urinary glycosaminoglycans }\end{array}$ \\
\hline \multicolumn{6}{|l|}{ MPS 3 (San filippo) } \\
\hline $\begin{array}{l}A \\
B\end{array}$ & $\begin{array}{l}252900 \\
252920\end{array}$ & $\begin{array}{l}\text { Heparan sulfate sulfatase } \\
N \text {-Acetyl- } \alpha \text {-D-glucosamidase }\end{array}$ & $\begin{array}{l}A R ; 17 q 25.3 \\
A R ; 17 q 21\end{array}$ & $\begin{array}{l}\text { Occasional lymphocytes with } \\
\text { occasional vacuoles; metachromatic }\end{array}$ & $\begin{array}{l}\text { Enzyme assay on white blood cells; } \\
\text { urinary glycosaminoglycans }\end{array}$ \\
\hline $\mathrm{C}$ & 252930 & $\begin{array}{l}\text { Acetyl-CoA- } \alpha \text {-glucosamide- } \\
N \text {-acetyl transferase }\end{array}$ & $\mathrm{AR} ; \mathrm{Chr} 14$ & inclusions in $>20 \%$ of lymphocytes & \\
\hline D & 252940 & $\begin{array}{l}\text { N-Acetyl glucosamine 6- } \\
\text { sulfatase }\end{array}$ & $A R ; 12 q 14$ & & \\
\hline \multicolumn{6}{|l|}{ MPS 4 (Morquio) } \\
\hline A & 253000 & $\begin{array}{l}\text { Galactosamine } 6 \text { sulfatase } \\
\text { deficiency }\end{array}$ & $A R ; 16 q 24.3$ & $\begin{array}{l}\text { No vacuoles; no metachromasia; } \\
\text { occasional basophilic inclusions; } \\
\text { small vacuoles in many lymphocytes; } \\
\text { no metachromasia }\end{array}$ & $\begin{array}{l}\text { Enzyme assay on white blood cells; } \\
\text { undetectable } \beta \text { galactosidase activity } \\
\text { in blood films; urinary } \\
\text { glycosaminoglycans }\end{array}$ \\
\hline B & 253010 & $\beta$ Galactosidase deficiency & AR; ??3p21.33 & & \\
\hline MPS 6 (Maroteaux-Lamy) & 253200 & Aryl sulfatase B deficiency & $A R ; 5 q 11-q 13$ & $\begin{array}{l}\text { Small vacuoles present in a } \\
\text { considerable number of lymphocytes; } \\
\text { metachromatic inclusions in } \\
\text { lymphocytes; Alder granulation } \\
\text { (basophilic, birefringent, } \\
\text { metachromatic granules) in all } \\
\text { neutrophils }\end{array}$ & $\begin{array}{l}\text { Enzyme assay of white blood cells; } \\
\text { urinary glycosaminoglycans }\end{array}$ \\
\hline MPS 7 & 253220 & $\beta$ Glucuronidase deficiency & $A R ; 7 q 21.11$ & $\begin{array}{l}\text { Occasional lymphocytes with small } \\
\text { vacuoles }\end{array}$ & $\begin{array}{l}\text { Enzyme assay of white blood cells; } \\
\text { urinary glycosaminoglycans; } \\
\beta \text { glucoronidase activity absent in } \\
\text { lymphocytes and neutrophils in blood } \\
\text { films }\end{array}$ \\
\hline Niemann-Pick A & 257200 & Sphingomyelinase deficiency & $\begin{array}{l}11 \mathrm{p} 15.4- \\
\text { pl5.1 }\end{array}$ & $\begin{array}{l}1-6 \text { small vacuoles in most } \\
\text { lymphocytes }\end{array}$ & Enzyme assay of white blood cells \\
\hline Fucosidosis & 230000 & $A$-L-Fucosidase & AR $1 \mathrm{p} 34$ & $\begin{array}{l}\text { Small discrete vacuoles in } \\
\text { lymphocytes }\end{array}$ & Enzyme assay of white blood cells \\
\hline $\begin{array}{l}\text { Juvenile Batten's disease } \\
\text { (NCL3) }\end{array}$ & 204200 & Not known & AR 16p12.1 & $\begin{array}{l}\text { Numerous, large, bold vacuoles in } \\
\text { considerable number of lymphocytes }\end{array}$ & $\begin{array}{l}\text { Molecular analysis shows a } 1 \text { kb } \\
\text { deletion in NCL3; skin biopsy shows } \\
\text { fingerprint inclusions in sweat glands } \\
\text { on electron microscopy; fingerprint } \\
\text { profiles can also be seen in some } \\
\text { lymphocytes on electron microscopy }\end{array}$ \\
\hline Mannosidosis & 248500 & $\alpha$ Mannosidase & $\begin{array}{l}\text { AR; } 19 \text { cen- } \\
\text { q12 }\end{array}$ & $\begin{array}{l}\text { Variable from numerous small } \\
\text { discrete to several large bold vacuoles } \\
\text { in lymphocytes }\end{array}$ & Enzyme assay of white blood cells \\
\hline Wolman's disease & 278000 & $\begin{array}{l}\text { Acid esterase (acid lipase, } \\
\text { acid cholesterol ester } \\
\text { hydrolase) }\end{array}$ & $\begin{array}{l}\text { AR; } 10 \mathrm{q} 24- \\
\mathrm{q} 25\end{array}$ & $\begin{array}{l}1-6 \text { small discrete vacuoles in most } \\
\text { lymphocytes, which stain positive } \\
\text { with oil red o or Sudan black lipid } \\
\text { stains }\end{array}$ & $\begin{array}{l}\text { Enzyme assay of white blood cells; } \\
\text { absence of acid esterase can be } \\
\text { detected in blood films }\end{array}$ \\
\hline
\end{tabular}




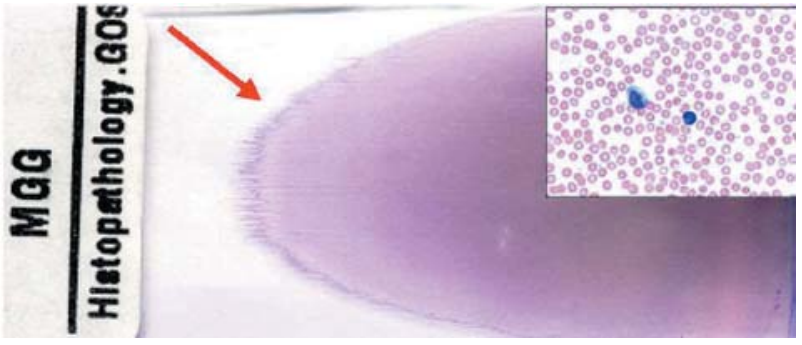

Figure 3 Low power image of a blood film, illustrating the correct area in which to look for the presence of vacuolated lymphocytes (arrow), and (inset) high power photomicrograph demonstrating a small lymphocyte and monocyte (May-Grunwald-Giemsa staining; original magnification, $\times 400$ ).

be noted that monocytes may also be present, and these should not be confused with lymphocytes, particularly because monocytes may show non-pathological cytoplasmic vacuolation. This appears to be more common when there has been a delay in making the films from the anticoagulated blood. The investigation requires about six blood films made from a few drops of an EDTA blood sample by a technician trained to make routine haematological blood films. A heparinised sample is also adequate. If there is need to examine a buffy coat by electron microscopy then an additional $1-2 \mathrm{ml}$ of EDTA blood is required. An average of 100 lymphocytes should be examined in a standard film, and if vacuolation is present, comments should be made as to the characteristics and extent of the vacuolation, as noted above and in table 3. Provided such criteria are used, false positive diagnosis should not occur, but false negatives may occur because in some cases the development of lymphocyte vacuolation may be progressive and only small numbers of lymphocytes may be affected, meaning that lymphocyte vacuolation may not be identified on a single blood film examination. If the clinical suspicion of a metabolic disease is high, repeat sampling may be indicated. In one series of 10 patients with juvenile neuronal ceroidlipofuscinosis (NCL3), vacuolated lymphocytes were present in $30-70 \%$ of cases examined, with the percentage of vacuolated lymphocytes increasing with the duration of the illness, especially in patients who were younger than 11 years of age. In that series, lymphocytes with fingerprint profiles on electron microscopic examination were only identified in just over $10 \%$ of cases. ${ }^{17}$ Similarly, in a series of cases of Salla disease (sialic acid storage disease), vacuolated lymphocytes were identified in only around $60 \%$ of cases. ${ }^{18}$ This may reflect the diversity of mutations in the gene encoding sialin (a sialic acid transporter protein), which is defective in this condition, or may be a further example of sampling issues as discussed above. $^{19}$ In addition to the examination of lymphocytes, observation of the morphology of other cell types can also provide valuable information. Neutrophils may show increased, coarse granulation-Alder granules in cases of Maroteaux-Lamy syndrome (MPS type VI) and $\beta$ glucuronidase deficiency. However, this must not be confused with toxic granulation present in patients with infections and other stresses, and can be excluded by metachromatic staining with birefringence. Eosinophil granules are often large and sparse in cases of GMI gangliosidosis and may also show cytoplasmic granulation.

In some cases, the clinical features in conjunction with the characteristics of the lymphocyte vacuolation if present are highly suggestive of a specific diagnosis, examples being the juvenile subtype of Batten's disease (NCL3) in a child with progressive blindness, ${ }^{20} 21$ and developmental deterioration or acid maltase deficiency disease in a patient with periodic acid
Take home messages

- The examination of blood films for lymphocyte vacuolation is clinically useful in patients with a history suggestive of metabolic disease

- A wide range of underlying metabolic diagnoses was apparent in patients with lymphocyte vacuolation, the most common being juvenile neuronal ceroid lipofuscinosis and acid maltase deficiency, which accounted for more than half of the diagnoses

- The test is cheap, rapid, minimally invasive, and provides a first line screening test, with some findings providing specific clues to the underlying diagnosis

Schiff positive lymphocyte vacuolation and progressive cardiac or skeletal myopathy. ${ }^{1}$ If the blood film contains lymphocytes with numerous prominent large vacuoles and there is a clinical suspicion of infantile GMI gangliosidosis, it may be possible to demonstrate $\beta$ galactosidase deficiency histochemically on the blood film. ${ }^{22}$ However, it is important to exclude other disorders, such as galactosialidosis, using enzymological methods. Similarly, histochemical detection of acid esterase activity is possible on blood films (showing lymphocytes with small numbers of small discrete vacuoles) to confirm or exclude the diagnosis of Wolman's disease. ${ }^{23}$ Furthermore, in addition to histochemical methods, ultrastructural examination of the inclusions may allow further specific diagnosis and has particularly aided the identification of variant subtypes of Batten's disease. In classic infantile-type Batten's disease (NCL1) ultrastructural examination demonstrates granularosmophilic deposits; the late infantile type (NCL2) is associated with curvilinear bodies and the juvenile form (NCL3) with fingerprint inclusions. ${ }^{1} 2024$

\section{"Monocytes may also be present, and these should not be confused with lymphocytes, particularly because mono- cytes may show non-pathological cytoplasmic vacuola- tion"}

Nevertheless, it should be recognised that in some cases it may be difficult to make a comment regarding a specific diagnosis purely on the basis of lymphocyte vacuolation, and in all patients a diagnostic test should be undertaken to confirm a specific diagnosis. For this purpose, in most conditions in which definite specific diagnosis is possible, enzyme analysis of white blood cells or a fibroblast culture is considered the gold standard, although many such metabolic conditions are increasingly being associated with specific gene defects, which may be identified using molecular diagnostic techniques. ${ }^{25} 26$

In conclusion, our study has demonstrated the clinical usefulness of examining blood films for lymphocyte vacuolation in patients with a history suggestive of metabolic disease. The test is cheap, rapid, and minimally invasive and provides a first line screening test with findings in some cases, providing strong clues as to the underlying diagnosis, particularly when appropriate and adequate clinical information is provided.

\section{Authors' affiliations}

G Anderson, V V Smith, M Malone, N J Sebire, Department of Histopathology, Great Ormond Street Hospital, Great Ormond Street, London WCIN 3JH, UK 


\section{REFERENCES}

1 Lake BD. Blood, bone marrow, spleen and lymph nodes in metabolic disorders. In: Lake BD, Filipe MI, eds. Histochemistry in pathology. London: Churchill-Livingstone, 1990:303-18

2 Derwort A, Detering K. Vacuolated lymphocytes in familial amaurotic idiocy and their diagnostic significance. Nervenarzt 1959;30:442-8.

3 Baumann RJ, Markesbery WR. Juvenile amaurotic idiocy (neuronal ceroid lipofuscinosis) and lymphocyte fingerprint profiles. Ann Neurol 1978;4:531-6.

4 Lake BD, Cavanagh NP. Early-juvenile Batten's disease-a recognisable sub group distinct from other forms of Batten's disease. Analysis of 5 patients. J Neurol Sci 1978;36:265-71.

5 Aula P, Autio S, Raivio KO, et al. "Salla disease": a new lysosomal storage disorder. Arch Neurol 1979;36:88-94.

6 Terashima Y, Tsuda K, Isomura S, et al. I-cell disease. Report of three cases. Am J Dis Child 1975; 129:1083-90.

7 Cipolloni C, Boldrini A, Donti E, et al. Neonatal mucolipidosis II (I-cell disease) clinical, radiological and biochemical studies in a case. Helv Paediatr Acta 1980;35:85-95.

8 Fricker H, O'Brien JS, Vassella F, et al. Generalized gangliosidosis: acid betagalactosidase deficiency with early onset, rapid mental deterioration and minimal bone dysplasia. J Neurol 1976;213:273-81.

9 Giugliani R, Dutra JC, Pereira ML, et al. GM1 gangliosidosis: clinical and laboratory findings in eight families. Hum Genet 1985;70:347-54.

10 Goebel HH, Ikeda K, Schulz F, et al. Fingerprint profiles in lymphocytic vacuoles of mucopolysaccharidoses I-H, II, III-A, and III-B. Acta Neuropathol $1981 ; 55: 247-9$

11 Rossier A, Caldera R, Sarrut S. A pathognomonic sign of Niemann-Pick disease: vacuolated lymphocytes. Arch Fr Pediatr 1959;16:1358-61.

12 Loeb $\mathrm{H}$, Tondeur $\mathrm{M}$, Jonniaux $\mathrm{G}$, et al. Biochemical and ultrastructural studies in a case of mucopolysaccharidosis " $\mathrm{F}$ " (fucosidosis). Helv Paediatr Acta 1969:5:519-37.

13 Desnick RJ, Sharp HL, Grabowski GA, et al. Mannosidosis: clinical, morphologic, immunologic, and biochemical studies. Pediatr Res 1976;10:985-96.
14 Bona G, Bracco G, Gallina MR, et al. Wolman's disease: clinical and biochemical findings of a new case. J Inherit Metab Dis 1988; 11:423-4.

15 von Bassewitz DB, Bremer HJ, Bourgeois M, et al. Vacuolated lymphocytes in type II glycogenosis - a diagnostic approach? Eur J Pediatr 1977; 127:1-7.

16 Armitage P, Berry G, Matthews JNS. Statistical methods in medical research, 4th ed. Oxford: Blackwell Science, 2002.

17 Kimura S, Goebel HH. Light and electron microscopic study of juvenile neuronal ceroid-lipofuscinosis lymphocytes. Pediatr Neurol 1988;4:148-52.

18 Simila S, Linna SL, Vayrynen M, et al. Finnish type of sialic acid storage disease with sialuria (Salla disease): the occurrence and diagnostic significance of cytoplasmic vacuoles in blood lymphocytes. J Ment Defic Res 1985;29:179-86.

19 Wreden CC, Wlizla M, Reimer RJ. Varied mechanisms underlie the free sialic acid storage disorders. J Biol Chem 2005;280:1408-16.

20 Aberg L, Jarvela I, Rapola J, et al. Atypical juvenile neuronal ceroid lipofuscinosis with granular osmiophilic deposit-like inclusions in the autonomic nerve cells of the gut wall. Acta Neuropathol 1998;95:306-12.

21 Santavuori P, Vanhanen SL, Autti T. Clinical and neuroradiological diagnostic aspects of neuronal ceroid lipofuscinoses disorders. Eur J Paediatr Neurol 2001;5(suppl A):157-61.

22 Lake BD. An improved method for the detection of $\beta$-galactosidase activity, and its application to GM1-gangliosidosis and mucopolysaccharidosis. Histochem J 1974;6:211-18.

23 Lake BD. Histochemical detection of the enzyme deficiency in blood films in Wolman's disease. J Clin Pathol 1971;24:617-20.

24 Brod RD, Packer AJ, Van Dyk HJ. Diagnosis of neuronal ceroid lipofuscinosis by ultrastructural examination of peripheral blood lymphocytes. Arch Ophthalmol 1987; 105:1388-93.

25 Parker CC, Evans OB. Metabolic disorders causing childhood ataxia. Semin Pediatr Neurol 2003;10:193-9.

26 Prasad AN, Prasad C. The floppy infant: contribution of genetic and metabolic disorders. Brain Dev 2003;25:457-76. 